$\mathrm{A} \int_{\cos } \mathrm{H}$

Article history :

Received : 04.12.2014

Revised : 30.03.2015

Accepted : 16.04.2015

Members of the Research Forum

Associated Authors:

${ }^{1}$ Department of Horticulture, Faculty

of Agriculture, Annamalai

University, Annamalai Nagar,

CHIDAMBARAM (T.N.) INDIA

Email : kiransharaj@gmail.com

Author for correspondence :

R. RAJESWARI

Department of Horticulture, Faculty

of Agriculture, Annamalai

University, Annamalai Nagar,

CHIDAMBARAM (T.N.) INDIA

Email : rajihorti@gmail.com
THEASIAN JOURNAL OF HORTICULTURE

Volume 10 | Issue 1 | June, 2015 | 71-75

Visit us -www.researchjournal.co.in

\title{
Influence of season and spacing on the growth performance of ambrette (Abelmoschus moschatus Medic.)
}

\section{R. RAJESWARI AND ARUMUGAM SHAKILA ${ }^{\mathbf{1}}$}

ABSTRACT : An investigation was undertaken to study the influence of season and spacing on the growth performance of ambrette (Abelmoschus moschatus Medic.). The field experiment was conducted in two seasons viz., January to June (season I) and July to December (season II) with five spacing levels $\left(T_{1}-60 \mathrm{~cm} \times 30 \mathrm{~cm} ; T_{2}-60 \mathrm{~cm} \times 45 \mathrm{~cm} ; T_{3}-60 \mathrm{~cm} \times 60 \mathrm{~cm} ; T_{4}-75\right.$ $\mathrm{cm} \times 60 \mathrm{~cm} ; \mathrm{T}_{5}-75 \mathrm{~cm} \times 75 \mathrm{~cm}$ ). The design followed was Randomized Block Design with four replications. The observations regarding plant height, number of branches, stem girth, internodal length, number of leaves and leaf area were recorded and analysed statistically. The results revealed that the seeds sown during July to December (season II) with a spacing of $60 \mathrm{~cm} \times 60$ $\mathrm{cm}$ recorded the highest values for the above growth characters in ambrette.

KEY WORDS : Ambrette, Season, Spacing, Plant density

HOW TO CITE THIS ARTICLE : Rajeswari, R. and Shakila, Arumugam (2015). Influence of season and spacing on the growth performance of ambrette (Abelmoschus moschatus Medic.). Asian J. Hort., 10(1) $: 71-75$. 